\title{
THE IMPACT OF THE CORPORATE CULTURE ON THE SUCCESS OR THE FAILURE OF MERGERS AND ACQUISITIONS
}

\author{
Robin Kazík
}

Klíčová slova:

M \& A, fúze, akvizice, post-akviziční fáze, PMI, firemní kultura

Key words:

M\&A, merger, acquisition, post-merger, PMI, corporate culture

\begin{abstract}
Abstrakt
Tato práce je př́spěvkem $\mathrm{k}$ diskuzi na téma úspěšnosti fúzí a akvizic a dopadu korporátní kultury na úspěšnost těchto akcí. Publikované studie ukazují velmi vysoké procento selhání těchto transakcí. Na konkrétních výzkumech, především ze zahraničí, bych chtěl poukázat, že jedním z hlavních důvodů negativních výsledků je podceňování post-integračních procesů a střetu korporátních kultur. Výzkumy $\mathrm{z}$ této oblasti jsou srovnány s vlastním pilotním výzkumem mezi specialisty z řad transakčních poradců, kteří se zabývají realizací těchto transakcí. Z výsledků tohoto srovnání je patrné, že střet firemních kultur patří také v České republice mezi rizika ohrožující úspěšnou integraci. Při plánování transakce je nutné brat $\mathrm{v}$ potaz, že lidé nemají rádi změny a věnovat harmonizaci firemních kultur dostatečnou pozornost.
\end{abstract}

\begin{abstract}
This work is devoted to the issue of mergers and acquisitions, as well as contribution to the discussion about the corporate culture impact on post-merger integration and success of these transactions. The studies have shown relatively high percentage of failure of these transactions caused by underestimating cultural impact in post-merger integration. Foreign surveys are compared with my research realized among companies after M\&A transaction and among transaction advisers from the Czech Republic. The results of this comparison indicate that the clash of the corporate cultures represents the one of the threats to the transaction success. Management should assume that people do not like changes and there is necessary to pay enough attention to the corporate culture harmonization.
\end{abstract}

\section{Introduction}

Are mergers and acquisitions appropriate tools to achieve business goals? Do potential benefits outweigh the risks? What is the failure probability? What are the most common postmerger failures?

With the release of geographic, political and regulatory barriers in recent decades there has been a sudden increase in the volume of M\&A transactions worldwide. Activities in the area of mergers and acquisitions have penetrated into most economic areas. The amount of cross- 
border transactions has dramatically increased compared to previous decades. The aim of my contribution is to show the long-lasting failure rate of M\&A transactions. As resources there were used published analysis, researches, statistic, literature research, own research and interviews with executives.

\section{The risks of transactions of mergers and acquisitions}

The history of modern transactions of mergers and acquisitions is lasting over two decades in the Czech Republic. With the gradual releasing of the barriers to the free market and harmonization of the legislation with the EU, there was a rapid development of M\&A transactions in our country. However the results from the western countries show that for the long period M\&A have been highly overrated as tools for achieving the corporate aims. Not only that there are often unfulfilled M\&A objectives, but also the high percentage of transactions lead to economic and financial losses, or even to business value decrease. Despite these problems are M\&A very popular management tools. The mail omission appears to be underestimating integration time demands, difficulty of synergies quantification, the different objectives of management and owners, and many others.

\section{Selected studies of surveyed topic}

The main objective of M\&A is to increase the market value of the company. Studies have shown a relatively high percentage of failure of these transactions. Management is often willing to go to great risks expecting synergistic effects, but synergistic effects are usually difficult to pre-evaluate and often do not coincide with the achieved reality.

Selected studies focused on the success or the failure of M\&A transactions.

- Michael Porter, who analyzed over the 2700 M\&A transactions of 33 major companies in the U.S. for 36 years from 1950 to 1986, concluded that the failure rate of M\&A transactions ranges between $50-75$ percent $^{1}$.

- According to KPMG statistics "Value Enhancement Trends"2 (Graph 1) indicators show that most M\&A transactions end up with companies' market value decrease, or have no positive influence on market value.

\footnotetext{
${ }^{1}$ SCHNERIDER, Wiliam. Merger or Acquisition Failing? The Solution Lies in Your Strategic Focus [online]. [cit. 2008-02-20].

${ }^{2}$ KPMG. All to play for, striving for post deal success [online] . [cit. 2008-10-01].
} 


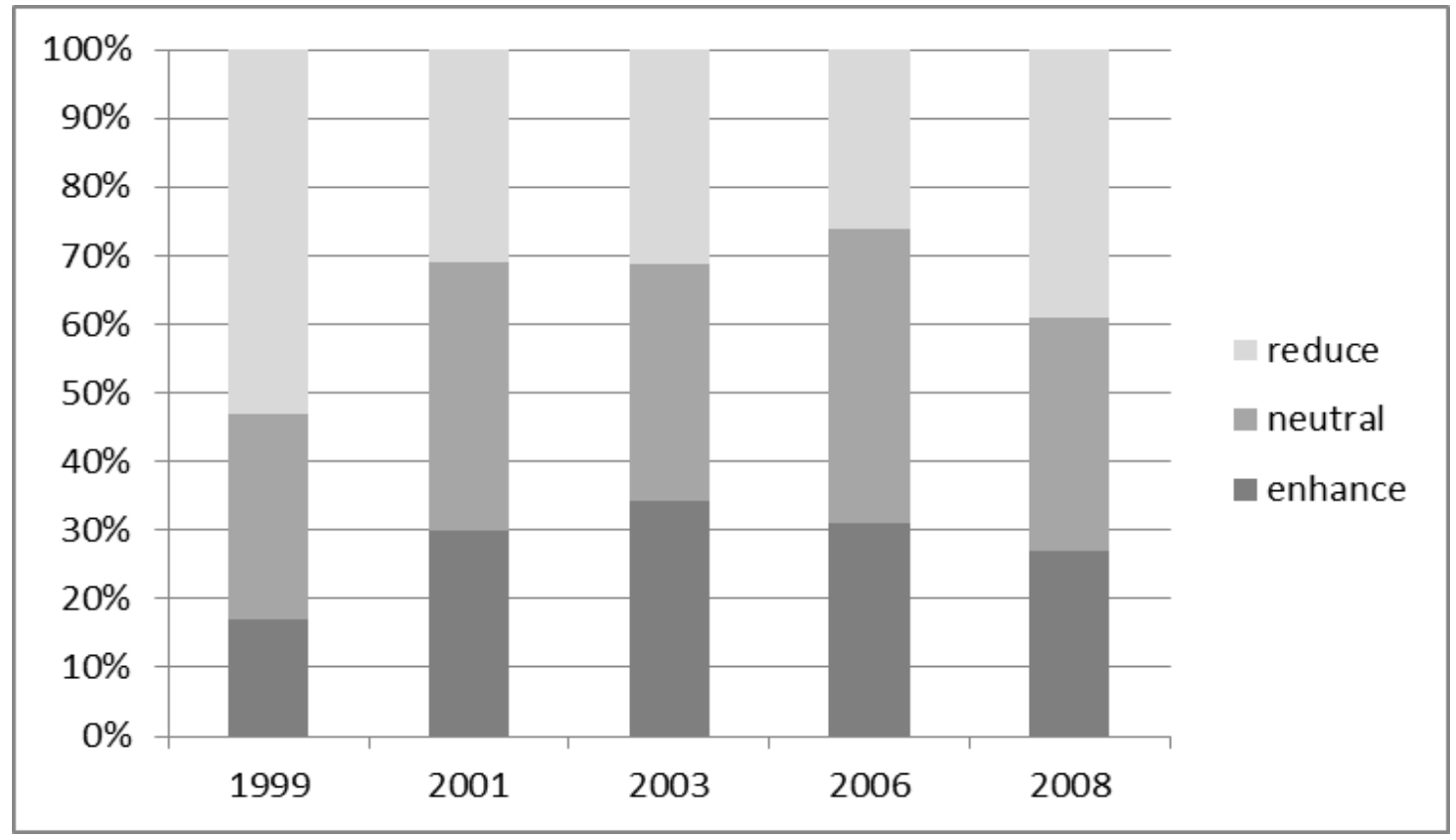

Source: KPMG

- According to the Deloitte study $70 \%$ of M\&A transactions do not meet the expected effects and aims. The period between the 4th and 8 months after acquisition often brings a significant decline of company activity. Within 12 months after the merger $47 \%$ managers have left. Within three years there have been up to three quarters of managers leaving the company. Mike Jennings from Deloitte: "Experience suggests that the actual benefits gained from joining are usually disappointing ". ${ }^{3}$

- According to a study by JP Morgan ${ }^{4}$ more than half of all M\&A transactions worldwide had not met planned targets. Therefore it could be said that the amount of bad investments is in total 1.6 trillion USD.

- Another view can provide us study by Cartright and Cooper ${ }^{5}$ which states that none of the 40 examined companies included analysis of human resources and the corporate culture in the process of due diligence.

- Stanislav Konkolski's research from 2000-2009 participated 29 companies which were involved in 19 of M\&A transactions in the area of the Czech Republic resulted the fact that from the total of the 19 transactions were only 5 successful, 12 unsuccessful, and two transactions ended up with the same result as before and after the transaction. Only one-third of surveyed transactions increased the value of EVA and more than $(63,2 \%)$ half of the surveyed transactions had not yielded the EVA value decrease. $^{6}$

${ }^{3}$ BUŘÍK, Lukáš. Pouhá třetina fúzí a akvizic naplni očekávání [online]. [cit. 2007-06-15].

${ }^{4}$ SCHNERIDER, Wiliam. Merger or Acquisition Failing? The Solution Lies in Your Strategic Focus [online]. [cit. 2008-02-20].

${ }^{5}$ WARRILOW, Stephen. Merger failures, value destruction and cultural conflicts [online]. [cit. 2010-06-8].

${ }^{6}$ KONKOLSKI, Stanislav. Strukturalizace a analýza faktorů ovlivňujících efektivnost fúzí a akvizic. 2011, p. 113 -116 . 


\section{Selected studies focusing on the reason of failure of M\&A transactions.}

- A survey conducted by A.T. Kearney identifies the most critical phase to success or merger failure revealed that whilst the majority of $53 \%$ stressed that the actual implementation phase - often A.T. Kearney referred to as the "post-merger integration" phase - bears the greatest risk - this post-acquisition phase is the most ignored. $^{7}$

- Although human resources is the fundamental determinant of the success or failure of the transaction, according to the magazine HR Works, Inc. even more than $85 \%$ of M\&A transactions ends unsuccessfully mainly because of lack of knowledge and underestimating the importance of human resource integration. Management often focuses the attention only on hard financial indicators and the attention on human resources is paid not earlier than in the post-merger process. Ronald Castor ${ }^{8}$, partner with JC Jones \& Associates LLC, dealing with services in M\&A says: "Excessive focus on financial and operational details at the expense of planning the integration of human resources has derailed many transactions." He suggests to reflect HR and culture aspects in the due diligence process. "Most companies would do well, to conduct due diligence that involves not just the balance sheet but also core values. " Also, Mike Osborn, CEO of Catalyst firm on the Rochester Top 100 company list, confirms the words: „Attention to HR issues in an acquisition should not be an afterthought. Strategic acquisitions are all about people.

- According to the Bureau of Business research at American International College, realized between the CFO and other top financial executives of 45 Forbes 500 companies, the number one reason why mergers and acquisitions fail is incompatibility of the corporate cultures. Dean of the Bureau of Business Research, Ira Smolowitz, says: "I knew culture was important, but I didn't think it would be most important. $" 9$

- According to Accenture research ${ }^{10}$ is the corporate culture considered by experts as the most critical factor for successful integration (38\% of respondents). Major determinant of the PMI outcome is the corporate culture, as a holder of behavioral norms, beliefs and company shared values.

- Lenka Niebauerová ${ }^{11}$ in her survey (Graph 2) identifies integration processes as the most problematic aspects of M\&A. Immediately in the wake of them is placed "synergies overestimation". Synergies often do not meet the expected results or due to the time delay do not come at all.

\footnotetext{
${ }^{7}$ SCHNERIDER, Wiliam. Merger Failures, Value Destruction and Cultural Conflicts - and How to Avoid Them! The Solution Lies in Your Strategic Focus [online]. [cit. 2009-04-18].

${ }^{8}$ WALTERS, Candace. How people-focused practices bolster M\&A success rates [online]. [cit. 2008-02-20]. ${ }^{9}$ SCHNERIDER, Wiliam. Merger or Acquisition Failing? The Solution Lies in Your Strategic Focus [online]. [cit. 2008-02-20].

${ }^{10}$ ACCENTURE. Coming out ahead, the role of finance in successful serial M\&A [online]. [cit. 2012-06-05].

${ }^{11}$ NIEBAUEROVÁ, Lenka. Strategická zmèna v organizaci formou fúze nebo akvizice. 2009. p. 46.
} 
Graph 2: What is behind the failure of $M \& A$ ?

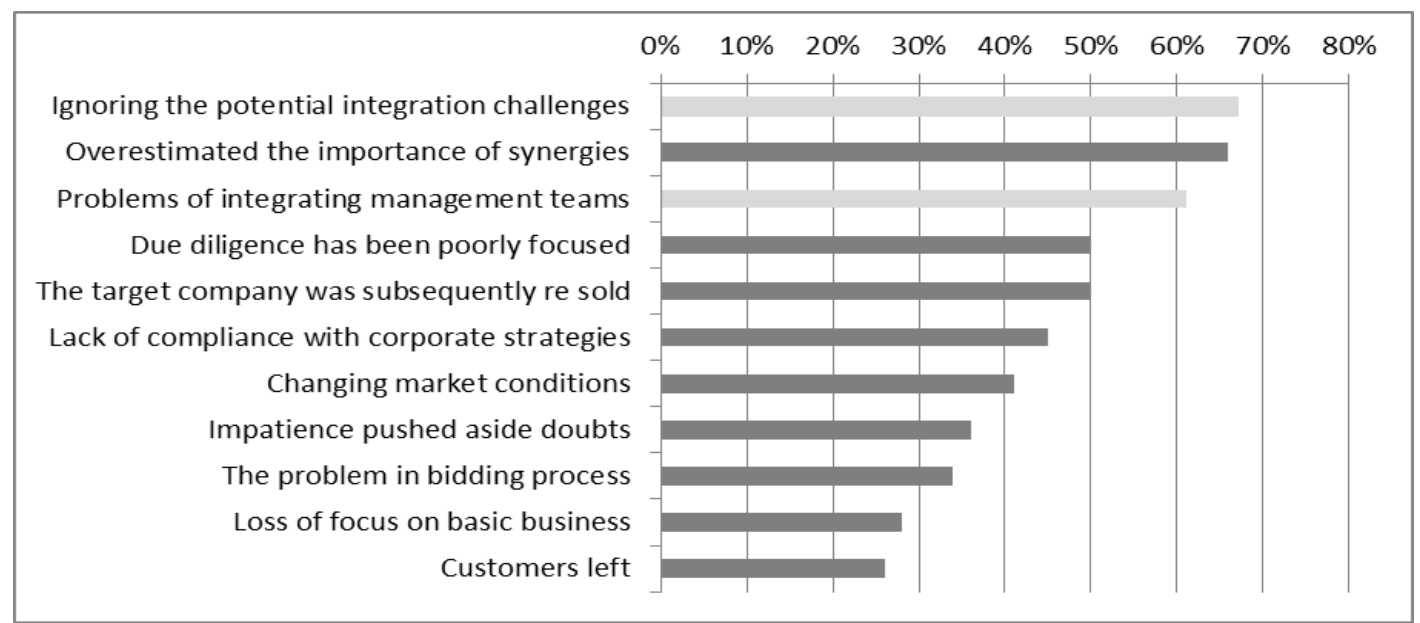

Source: NIEBAUEROVÁ, Lenka. Company's strategic change due to merger or acquisition

\section{Corporate culture and M\&A}

The corporate culture significantly affects the performance of the company and is especially beneficial in the employees' activity, commitment, initiative and also increases efficiency and quality. The benefits of the strong corporate culture on company's performance expressed by Lukášová a Nový ${ }^{12}$ :

- perception and thinking of workers is in harmony; low rate of unnecessary conflicts in communication,

- human behavior is automatically regulated; there is smaller need to coordinate all practices in the organization,

- enables quick decision making; consensus is easier to find,

- people in the organization shares common goals and values; actions lead to their fulfillment,

- increased motivation of individuals and groups; increased engagement, reduced the need for monitoring the workers performance.

Effective transfer of information and capabilities between the integrating partners and thus the use of synergies will only be successful if both partners show some understanding and respect of each other's organizational structures, processes, corporate culture and emotions. The willingness to understand, to cooperate and to create a common and better whole is considered to be as important as the availability of material resources. ${ }^{13}$

The corporate culture is primarily determined by daily behavior of management. People focus on what management do rather than on what they say. The corporate culture is deeply embedded within the organizational system. It cannot be taken out and dealt with in isolation. Culture is not amenable to being treated independently and attempts to do so will almost

\footnotetext{
${ }^{12}$ LUKÁŠOVÁ, Růžena., NOVÝ, Ivan a kol. Organizační kultura. 2004. p. 52.

${ }^{13}$ KUSSTATSCHER, Verena., COOPER, Lynn, Cary .Managing Emotions in Mergers And Acquisitions. 2005. p. 18.
} 
invariably result in failure. ${ }^{14}$ The failure of a merger is often attributed to a lack of attention to cultural integration and human resource issues. Human resources are one of the most important factors in merger projects. ${ }^{15}$

The results of the mentioned external surveys show that the major reasons of integration failures are in post-merger integration phase - PMI. It is obvious that the risk of culture impact in the PMI period does not attract enough management attention and is causing major economic losses. First impressions on the culture of the acquisition target may come up during the due dilligence, but are unlikely to influence the buying decision. As the companies have already invested much time and money they tentd to be unwilling to pull out of a potential deal. This stage is characterized by bidding and negotiations between the buyer and the seller. ${ }^{16}$

Management of transforming companies usually focuses on economic indicators and do not pay enough attention on the corporate cultures integration. It is clear that the corporate culture should be regarded as one of the pillars of success. Threatening results of underestimating the impact of the corporate culture on M\&A makes you wonder: How is it possible that management underestimated the corporate culture as the determinant of $M \& A$ ? There can be numerous reasons. ${ }^{17}$

- lacks of awareness of the existence of differences - managers do not understand that the corporate culture exists,

- lack of understanding - although managers know that the corporate culture exists, they do not understand the issue, or they do not want to deal with it or are underestimating its threat

- lack of readiness - a conscious decision not to deal with culture for such as the reasons as unattractiveness, fright of the unknown, or feeling that there is no real reason to care,

- lack of competence - management wants to do it appropriate, but do not know how.

HR department should be involved in the planning of integration process from the very beginning and not only after the implementation. In the PMI phase the management often focuses on solving thorny operational tasks. Compliance with this step plays an important role in the integration process and is an important starting point for the successful management of the transaction.

M\&A transactions place high demands on HR management, who bears significant responsibility on the final results. According to the Nový and Schroll-Machl ${ }^{18}$ management should be focused on ensuring following factors:

- provide HR factors and company culture depth analysis,

\footnotetext{
${ }^{14}$ CARLETON, Robert., LINEBERRY, Claude. Achieving post-merger success. 2004. p. 32.

${ }^{15}$ SCHULER, Randal., Jackson, Susan., HR issues and activities in mergers and acquisitions. European

Management Journal. 2001. p. 243.

${ }^{16}$ KUSSTATSCHER, Verena., COOPER, Lynn, Cary .Managing Emotions in Mergers And Acquisitions. 2005. p. 10.

${ }^{17}$ LUKÁŠOVÁ Růžena, NOVÝ, Ivan a kol. Organizační kultura. 2004. p.111.

${ }^{18}$ NOVÝ, Ivan., SCHROLL-MACHL, Sylvia, S. Spolupráce pres hranice kultur. 2005. p. 99.
} 
- establish a clear integration strategy,

- create conditions for active communication between all stakeholders,

- ensure management concentration on the integration phase.

There is necessary to thoroughly analyze the initial state of integrating companies before human resources integration planning and the corporate culture. Analysis of the corporate culture aim to precise identification of the individual factors of the corporate culture, assessing their compatibility and proposing targeted solutions and steps leading to it.

It is naive to expect that acquisition, mergers or other organizational alliances will be made exclusively on the basis of their culture match, but at present it would seem that insufficient consideration is given to this increasingly significant issue. However, knowing and appreciating the culture of own organization, and that of any potential or newly acquired organization or merger partner, is an important first step in assessing future capability and the likelihood of a potentially smooth and relatively unproblematic post-merger. ${ }^{19}$

The integration strategy may be planned on analysis' results defining problematic factors, evaluating individual components of resistance to target state. In my opinion, there is necessary to assume following factors in the process of planning:

- employees do not like changes and understand them as the threat,

- the rules and procedures functioning well in one company do not necessarily work in the acquiring company,

- communication should be focused on dialog and not a monologue,

- final culture should reflect core values of both companies,

- it is necessary to understand the environment of integrating company determined by methods of decision-making and the corporate culture,

- it is necessary to formulate a new role of individual organizational units in a newly established company and through dialogue achieve compliance in the perception of new responsibilities and roles.

Main target of the corporate culture integration is to prevent unnecessary conflict and resistance to acceptance of new identity. Communication both vertical and horizontal is considered as one of key success factors. ${ }^{20}$ When the situation escalates there may be cases where new co-workers are unable to cooperate in harmony and find agreement. Different habits of solving problems may cause unnecessary conflicts. The main negative results of this condition are the decrease of productivity, workers frustration and unnecessary problems. If this situation lasts for longer period there is need for radical change among opponents of the new the corporate culture. There must be assumed that people do not like the changes and innovations are tent to dismissive skepticism when planning the integration process.

\footnotetext{
${ }^{19}$ CARTWRIGHT, Sue., COOPER, Lynn, Cary. Managing Mergers Acquisitions and Strategic Alliances. 1996. p.58.

${ }^{20}$ SCHULER, Randal., Jackson, Susan., HR issues and activities in mergers and acquisitions. European Management Journal. 2001. p. 242.
} 


\section{Indicative research}

I would like to outline the situation in the Czech Republic by referring to own indicative research, whether management in the Czech Republic, puts emphasis on the integration of the corporate cultures at early acquisition planning or not. Respondents were drawn from companies that have undergone M\&A transaction in the recent past. The first step of the survey was focused on getting contacts on the top management through telephone inquiries. In the next step there was the management, who was previously involved in the transaction contacted by email with request to cooperate. Immediately afterwards were the transactions manager contacted by telephone with request for cooperation. There had been data obtained only from 7 companies out of 31 contacted companies after M\&A. From interviews it was clear that management is not prepared to audit their work and get feedback.

The results show that in all cases the management planned new organizational structure; in contrast, 5 respondents stated the fact that management did not consider paying enough attention to the formal the corporate culture. 3 respondents who reported that the culture integration plan was done and stated classical forms of culture integration such as: intranet, team building, company party and corporate newspapers. Only one of surveyed companies paid attention to this issue already in the process of due diligence. Respondents stated the integration of human resources as unexpected problem. Employees are conflict-free but they do not share common values within the company.

Investigation among management was therefore supplemented with the survey among transaction advisors. Transaction advisors were chosen because they are dealing with numerous numbers of $M \& A$ and their view on transactions brings us relevant informational value. The research objective is to identify the motives and risks of transactions and determine whether the Czech market faces challenges similar to those foreign markets. For the survey there was used Cameron's and Quinn's ${ }^{21}$ analysis of substantive component of the corporate culture. Research was conducted through a questionnaire survey and interviews among specialists dealing with the issue of mergers and acquisitions. The data had been obtained from 13 transaction advisors from (out of 21 requested) companies: A\&CE Consulting, Corsum Group, Havel, Holásek \& Partners, Mazars, Patria Finance, PricewaterhouseCoopers, HR Partners - Traficon Market Company, Venture Investors Corporate Finance, Weinhold Legal.

Transaction advisers were asked to identify the most common reasons of failure of M\&A transactions in the Czech Republic. The percentage rate mentioned in brackets represents the average value of respondents' answers to the maximum possible assessment.

As the most frequent reason for the failure had been reported the unexpected change in market conditions (75\%). Furthermore, according to the obtained values: overestimation of synergies $(65 \%)$, followed by reasons with the highest dispersion rate (where respondents were disunited in their responses); conflict of the corporate cultures (62\%); different aims of management and owners (62\%), reasons with a relatively high dispersion rate; poor management integration $(60 \%)$; undervalued time demand $(58 \%)$; miscalculation, poor due diligence $(56 \%)$; exaggerated optimism in funding planning $(56 \%)$; too much operative put aside initial targets $(51 \%)$; company culture had not been solved in the preparatory phase $(47 \%)$; failure of system integration tools and procedures (45\%); fluctuations (42\%).

${ }^{21}$ CAMERON, K.S., QUINN, R.E. Diagnosting and changing organizational culture. 2005. p. 32. 
The following section assesses the post integration steps in the term of importance. Experts also assigned own opinion on the level of ignoring certain process by management during the implementation. The percentage rate mentioned in brackets expresses the importance of the process for the success of the transaction. Rating of marginalization is expressed verbally, if deviates from the average values. The percentage rate mentioned in brackets represents average value of respondents' answers to the maximum possible assessment.

As the most important process experts judged communication with customers (89\%). This process also achieved the lowest rate of marginalization. Furthermore followed by two steps with relatively low marginalization rate: definition of responsibilities $(84 \%)$; establishment of internal communication and information flows (82\%). Next is the financial management methods integration $(80 \%)$, formation of the new management $(80 \%)$. Steps listed according to the achieved ranking of importance: commerce and sales integration (76\%); communication of the merger within the company $(75 \%$, relatively high value of marginalization); information systems integration (75\%, with relatively higher dispersion the previously valued step).

The integration steps with extremely high value level of marginalization rate: management methods harmonization (71\% importance, $74 \%$ marginalization rate); integration of human resources (71\% importance, $64 \%$ rate marginalization). Steps with very low marginalization rate: organizational structures integrations (71\%); logistics and marketing systems integration (70\%). Against expectations specialists also consider marketing and corporate identity as one of the marginalized steps. Harmonization of the remuneration system and benefits $(67 \%)$ achieved the same rating of as importance of harmonization of accounting and tax systems $(67 \%)$, but is evaluated as more marginalized. The integration of the corporate cultures achieved a low importance rating $(65 \%)$, but had the second highest value of marginalization rate. Connection of customer service $(65 \%)$, which achived slightly greater marginalization rate than trade activities integration; the standardization of system tools and procedures $(64 \%)$; integration of financial flows (60\%); harmonization of human resources $(60 \%)$.

\section{Conclusion}

The aim of my paper is to map the issues related to M\&A transactions and to highlight longterm high failure rate of these transactions. Selected studies mentioned in section 2. of this article show high failure rate of M\&A transactions in the last 50 years and declare that the integration may creates numbers of negative effects. These negative effects often threat not only the integration targets, but also the market value and the basic functioning of the company.

The information from external sources and own indicative research show that most companies do not consider integration of human resources as an essential determinant and often do not pay attention to culture integration. The clash of the corporate cultures was assessed by the transaction advisors as one of the threats in post-merger integration phase. It should be also mentioned that the unpredicted length of due diligence and the operative management of integration often delay the desired gain of competitive advantages and so they are no longer considered as an advantage. Planned synergies as targets are also problematic because they are very difficult to measure and often represent only wishes of management than quantified targets. In recent times experts tend to believe that M\&A transactions can be replaced by internal expansion. 
The main message of my post is to point out that culture and quality of human resources belongs to the determinants of M\&A and management should pay attention to successful culture integration which is beneficial primarily in the activity of employees, commitment, initiative but also in employee innovation, increased efficiency and work quality. The culture significantly affects the performance of the company and therefore it is necessary to learn from the past mistakes and begin to consider culture as one of the essential elements in due diligence phase.

\section{Literature:}

[1] SCHNERIDER, Wiliam. Merger or Acquisition Failing? The Solution Lies in Your Strategic Focus [online]. [cit. 2008-02-20]. Retrieved from: http://ezinearticles.com/?expert=William_Schneider,_Ph.D.

[2] KPMG. All to play for, striving for post deal success [online] . [cit. 2008-10-01]. Retrieved from: http://www.kpmg.com/global/en/issuesandinsights/articlespublications/all-to-play-forpost-deal-success/Pages/default.aspx.

[3] BUŘÍK, Lukáš. Pouhá třetina fúzí a akvizic naplni očekávání [online]. [cit. 2007-0615]. ]. Retrieved from: www.finance.cz/zpravy/finance/115782-pouha-tretina-fuzi-aakvizic-naplni-ocekavani.

[4] SCHNERIDER, Wiliam. Merger or Acquisition Failing? The Solution Lies in Your Strategic Focus [online]. 2012 [cit. 2008-02-20]. Retrieved from: http://ezinearticles.com/?expert=William_Schneider,_Ph.D.

[5] WARRILOW, Stephen. Merger failures, value destruction and cultural conflicts [online]. 2012 [cit. 2010-06-8]. Retrieved from: http://www.strategies-for-managingchange.com/merger-failures.html.

[6] KONKOLSKI, Stanislav. Strukturalizace a analýza faktorů ovlivňujících efektivnost fúzí a akvizic. In: Acta academica karviniensia, roč. 2011, č. 4. Karviná: SU OPF, 2011, p. 104 - 124. ISSN 1212-415X.

[7] SCHNERIDER, Wiliam. Merger Failures, Value Destruction and Cultural Conflicts and How to Avoid Them! The Solution Lies in Your Strategic Focus [online]. 2012 [cit. 2009-04-18]. Retrieved from:

http://www.evancarmichael.com/Management/5182/Merger-Failures-ValueDestruction-and-Cultural-Conflicts--and-How-to-Avoid-Them.html.

[8] WALTERS, Candace. How people-focused practices bolster M\&A success rates [online]. 2012 [cit. 2008-02-20]. Retrieved from:http://www.hrworks-inc.com/oursolutions/hr-benefits-consulting/hr-and-benefits-consulting-articles/71-how-peoplefocused-practices-bolster-ma-success-rates.

[9] SCHNERIDER, Wiliam. Merger or Acquisition Failing? The Solution Lies in Your Strategic Focus [online]. 2012 [cit. 2008-02-20]. Retrieved from: http://ezinearticles.com/?expert=William_Schneider,_Ph.D.

[10] ACCENTURE. Coming out ahead, the role of finance in successful serial M\&A [online]. 2012 [cit. 2012-06-05]. Retrieved from: http://www.accenture.com/SiteCollectionDocuments/PDF/Accenture-Coming-outAhead-The-Role-of-Finance-in-Successful-Serial-MAndA.pdf.

[11] NIEBAUEROVÁ, Lenka. Strategická změna v organizaci formou fúze nebo akvizice. Brno, 2009. 125 p.Disertační práce. Vysoké učení technické v Brně, Fakulta podnikatelská, Ústav informatiky. 
[12] LUKÁŠSVÁ Růžena., NOVÝ, Ivan. a kol. Organizační kultura. Praha: Grada Publishing, 2004. 174 p. ISBN 80-247-0648-2.

[13] KUSSTATSCHER, Verena., COOPER, Lynn, Cary. Managing Emotions in Mergers And Acquisitions. Cheltenham: Edward Elgar Publishing, 2005. 212 p. ISBN: 978184542081.

[14] CARLETON, Robert., LINEBERRY, Claude. Achieving post-merger success. San Francisco: Pfeiffer, 2004. 213 p. ISBN 0787964905.

[15] SCHULER, Randal., Jackson, Susan., HR issues and activities in mergers and acquisitions. European Management Journal. Elsevier, 2001. p. 239-253. ISSN: 02632373.

[16] KUSSTATSCHER, Verena., COOPER, Lynn, Cary. Managing Emotions in Mergers And Acquisitions. Cheltenham: Edward Elgar Publishing, 2005. 212 p. ISBN: 978184542081.

[17] LUKÁŠOVÁ, Růžena., NOVÝ Ivan. a kol. Organizační kultura. Praha: Grada Publishing, 2004. 174 p. ISBN 80-247-0648-2.

[18] NOVÝ, Ivan., SCHROLL-MACHL, Sylvia. Spolupráce přes hranice kultur. Praha: Management Press, 2005. 313 p. ISBN 80-7261-121-6.

[19] CARTWRIGHT, Sue., COOPER, Lynn, Cary. Managing Mergers Acquisitions and Strategic Alliances. Oxford: Butterworth-Heinemann: 1996. 250 p. ISBN: 0 750623411.

[20] SCHULER, Randal., Jackson, Susan., HR issues and activities in mergers and acquisitions. European Management Journal. Elsevier, 2001. p. 239-253. ISSN: 02632373.

[21] CAMERON, K.S., QUINN, R.E. Diagnosing and changing organizational culture. London: John Wiley and Sons, 2005. 242 p. ISBN 07-8798-283-0.

\section{JEL M14, G34}

\section{Ing. Robin Kazík}

Obchodně podnikatelská fakulta v Karviné

Slezská univerzita v Opavě

Univerzitní náměstí 1934/3, 73340 Karviná

Tel.: 777103749

kazik@probull.cz 